\title{
Fiołek, stary dąb i Zagłada Język symboliczny Ihr Zuschauenden Nelly Sachs
}

Zacznę, nieco przewrotnie, od cytatu z... Adolfa Hitlera. Jeden z bon motów autora Mein Kampf miał brzmieć: „Sumienie to wynalazek żydowski. Jest jak obrzezanie, to okaleczanie istoty człowieka"1. Kiedy czytamy wiersz Nelly Sachs Ihr Zuschauenden (Wy, widzowie w tłumaczeniu Ryszarda Krynickiego), nie tyle trudno oprzeć się wrażeniu, że sumienie jest żydowskim wynalazkiem, ile trudno raczej znaleźć doskonalszą mistrzynię w budzeniu go niż owa żydowska poetka żyjąca na wygnaniu w Szwecji ${ }^{2}$. To, co w Führerze budziło odrazę (sumienie miało osłabiać niemieckiego ducha i tłumić dążenie do osiągnięcia przez naród panów „przestrzeni życiowej”), tu, w skromnym, ale jakże gęstym od znaczeń liryku, stało się dowodem tryumfu i ocalenia sumienia.

Interesujący mnie utwór pochodzi ze zbioru otwierającego w zasadzie twórczość Nelly Sachs - In den Wohnungen des Todes („W mieszkaniach śmierci”3)

${ }^{1}$ Słowa te miał wygłosić Hitler w jednej z prywatnych rozmów z prezydentem Senatu Wolnego Miasta Gdańska - Hermannem Rauschningiem. Rauschning przytacza je w swojej głośnej, choć dyskusyjnej ze względu na wartość źródłową książce Rozmowy z Hitlerem (Przeł. J. Hensel, R. Turczyn. Warszawa 1994, s. 239), zastrzegając się jednak: „[...] zanotowane wówczas zdania przytaczam poniżej, nie zawsze $\mathrm{w}$ dosłownym brzmieniu, wplatając okruchy innych rozmów” (tamże). Por. też ks. M. Czajkowski: Grzech antysemityzmu. „Więź” 1998, nr specjalny: Pod wspólnym niebem. Tematy polsko-żydowskie, s. 144.

${ }^{2} \mathrm{Na}$ temat roli etyki w jej twórczości zob. np. K.M. Bower: Ethics and Remembrance in the Poetry of Nelly Sachs and Rose Ausländer. Rochester 2000. „Poetką sumienia” nazwał Sachs również Stefan Lichański w tekście o takim właśnie tytule. Por. Tenże: Poetka sumienia. „Literatura na Świecie" 1976, nr 7, s. 339-343.

${ }^{3}$ Jeśli nie zaznaczono inaczej, tytuły i cytaty obcojęzyczne podano w tłumaczeniu autora artykułu - B.K. 
z 1947 roku$^{4}$. Ten niezwykle istotny dla całej światowej poezji tom odwołuje się wprost do Zagłady. Później poetka nie będzie już tak bezpośrednio wracać do tematyki Szoa. Pierwotnie ów zbiór miał się nazywać Dein Leib im Rauch durch die Luft (dosł. „Twoje ciało w dymie przez powietrze”), jednak na prośbę wydawcy - Aufbau-Verlag w Berlinie Wschodnim - tytuł został zmieniony. Fraza „Twoje ciało [to] dym w powietrzu” ${ }^{5}$ pochodziła z pierwszego, otwierającego książkę wiersza $O$ die Schornsteine („O, kominy”), który w angielskim tłumaczeniu jako $O$ the Chimneys dał z kolei tytuł pierwszej anglojęzycznej edycji z 1967 roku$^{6}$. Cały tom jest rodzajem lamentu za zmarłymi. Został dedykowany „moim zmarłym/zabitym braciom i siostrom” („Meinen toten Brüdern und Schwestern”), wspomniany utwór „O, kominy” zaś nosi niezwykle wymowne motto z Ksiegi Hioba $(19,26)$ :

Und wenn diese meine Haut zerschlagen sein wird, so werde ich ohne mein Fleisch Gott schauen.

W tłumaczeniu z języka hebrajskiego, dokonanym przez Izaaka Cylkowa:

Że następnie, gdy to ciało moje roztoczone będzie, jednak i wolen ciała ujrzę Boga!

Wy, widzowie to dwunasty utwór w tym tomie ${ }^{8}$. Dysponujemy dwoma polskimi przekładami tego wiersza, autorstwa wybitnych, choć bardzo różnych

${ }^{4}$ Przed wojną SACHS debiutowała tomem Legenden und Erzählungen ([„Legendy i opowiadania"]. Berlin 1921). Jego tematami przewodnimi były religia chrześcijańska i śmierć - symbol ofiary, a także przeżyta wcześniej miłość. Legenden und Erzählungen powstawały jako prywatne notatki. Poezję Sachs drukowały również w latach 30. XX wieku „Berliner Tageblatt” oraz „Der Morgen”. Dopiero jednak po wojnie jej twórczość została szerzej dostrzeżona. Podstawową, popularną pracą na temat poetki pozostaje książka Gabriele Fritsch-Vivié: Nelly Sachs. Monographie. 3. Aufl. Reinbek 2001. Zob. też J. Krawiecka: Niezwykłe życie niemieckiej noblistki Nelly Sachs (1891-1970). „Historic@” 2008, nr 3, s. 30-42.

5 Tak frazę „Dein Leib im Rauch durch die Luft” przetłumaczył Ryszard Krynicki.

${ }^{6}$ Zob. N. SAchs: O the Chimneys. Selected Poems, Including the Verse Play, ELI. New York 1967.

7 Zob. Księga Hioba. Przeł. I. Cylkow. Kraków-Budapeszt 2008, s. 85. Celowo, również na skutek sugestii Aliny Molisak, udzielonej podczas dyskusji na temat tego tekstu, powołuję się na tłumaczenie Biblii Hebrajskiej, a więc tradycji Nelly Sachs bliskiej, choć sama poetka nie znała języka hebrajskiego ani jidysz. Dla porządku dodam jeszcze, że ów fragment Księgi Hioba $(19,26)$ brzmi nieco odmiennie w innych translacjach. W Biblii Tysiąclecia: „Potem to [co zostało po zgniłym ciele - B.K.] skórą zostanie odziane, i ciałem swym Boga zobaczę”; w tłumaczeniu ks. Jakuba Wujka: „i znów obleczony będę w skórę moją i w ciele moim oglądać będę Boga mego”; a np. w protestanckiej Biblii Warszawskiej: „potem, chociaż moja skóra jest tak poszarpana, uwolniony od swego ciała będę oglądał Boga".

${ }^{8}$ W przypadku niemieckiej wersji wiersza korzystam ze zbiorowego wydania utworów poetki, por. N. SACHS: Werke. Kommentierte Ausgabe in vier Bänden. Bd. 1: Gedichte 1940-1950. Hrsg. M. Weichelt. Berlin 2010. 
poetów - Zbigniewa Herberta ${ }^{9}$ i Ryszarda Krynickiego ${ }^{10}$. Zestawiam oba tłumaczenia $\mathrm{z}$ oryginałem:

\begin{tabular}{|c|c|c|}
\hline i & $\begin{array}{r}\text { Tłu } \\
\text { Zbignie } \\
\text { Widz }\end{array}$ & $\begin{array}{r}\mathrm{T} \\
\text { Rysza } \\
W y, 2\end{array}$ \\
\hline $\begin{array}{l}\text { deren Blicken getötet } \\
\text { e. } \\
\text { man auch einen Blick } \\
\text { icken fühlt, } \\
\text { hlt ihr an euerm Leibe } \\
\text { licke der Toten. }\end{array}$ & $\begin{array}{l}\text { ych oczach zabija- } \\
\text { ię czuje spojrzenie } \\
\text { h } \\
\text { na waszym ciele } \\
\text { e umarłych. }\end{array}$ & $\begin{array}{l}\text { NA OCZACH KTÓRYCH } \\
\text { zabijano } \\
\text { Tak, jak się czuje czyjeś } \\
\text { spojrzenie na plecach, } \\
\text { Czujecie na swoim ciele } \\
\text { Spojrzenia umarłych. }\end{array}$ \\
\hline $\begin{array}{l}\text { Wieviel brechende Augen } \\
\text { werden euch ansehn } \\
\text { Wenn ihr aus den Verste- } \\
\text { cken ein Veilchen pflückt? } \\
\text { Wieviel flehend erhobene } \\
\text { Hände } \\
\text { In dem märtyrerhaft ge- } \\
\text { schlungenen Gezweige } \\
\text { Der al ten Eichen? } \\
\text { Wieviel Erinnerung wachst } \\
\text { im Blute } \\
\text { Der Abendsonne? }\end{array}$ & $\begin{array}{l}\text { Imierających oczu bę- } \\
\text { a was patrzeć, } \\
\text { vychylając się z kry- } \\
\text { zrywacie fiołek? } \\
\text { błagalnie podniesio- } \\
\text { ąk } \\
\text { ęczeńsko splątanych } \\
\text { ach } \\
\text { o dębu? } \\
\text { spomnień rośnie we } \\
\text { dzącego słońca? }\end{array}$ & $\begin{array}{l}\text { Ile gasnących oczu spojrzy } \\
\text { na was, } \\
\text { Kiedy będziecie zrywać fio- } \\
\text { łek z ukrycia? } \\
\text { Ile błagalnie uniesionych } \\
\text { rąk } \\
\text { W męczeńsko powykręca- } \\
\text { nych konarach } \\
\text { Starych dębów? } \\
\text { Ile wspominania rośnie we } \\
\text { krwi } \\
\text { Zachodzącego słońca? }\end{array}$ \\
\hline $\begin{array}{l}\text { O die ungesungenen Wie- } \\
\text { genlieder } \\
\text { In der Turteltaube Nachtruf } \\
\text { - } \\
\text { Manch einer hätte Sterne } \\
\text { herunterholen können, } \\
\text { Nun muss es der alte Brun- } \\
\text { nen für ihn tun! }\end{array}$ & $\begin{array}{l}\mathrm{O} \text {, nie wyśpiewane kołysan- } \\
\mathrm{ki} \\
\mathrm{W} \text { nocnym wołaniu turkaw- } \\
\mathrm{ki}- \\
\text { Jeszcze jeden jej głos mógł- } \\
\text { by ściągnąć gwiazdę, } \\
\text { A teraz musi to uczynić } \\
\text { Stara studnia. }\end{array}$ & $\begin{array}{l}\text { O, niezaśpiewane kołysanki } \\
\text { W nocnym nawoływaniu } \\
\text { turkawki- } \\
\text { Niejeden mógłby ściągnąć } \\
\text { na dół gwiazdy, } \\
\text { Teraz stara studnia musi to } \\
\text { czynić za niego! }\end{array}$ \\
\hline $\begin{array}{l}\text { ar Zuschauenden, } \\
\text { ie ihr keine Mörderhand } \\
\text { rhobt, }\end{array}$ & $\begin{array}{l}\text { pod- } \\
\text { ki }\end{array}$ & $\begin{array}{l}\text { Wy, widzowie, } \\
\text { Którzy nie podnosiliście } \\
\text { morderczej ręki }\end{array}$ \\
\hline
\end{tabular}

9 Zob. N. SAchs: Widzowie. Przeł. Z. Herbert. „Poezja” 1967, nr 2, s. 49 (przedruk: „Zeszyty Literackie” 2001, nr 74, s. 40). Jak czytamy w „Zeszytach Literackich” (s. 39): „Za zgodą Katarzyny Herbertowej i spadkobierców przedstawiamy przekłady Zbigniewa Herberta, które nie doczekały się wydania książkowego".

${ }^{10}$ Zob. N. Sachs: Wy, widzowie. Przeł. R. Krynicki. W: N. Sachs: Rozżarzone zagadki. Wiersze wybrane. Wybór i przeł. R. KRYNICKI. Kraków 2006, s. 13. 


\begin{tabular}{|l|l|l|l|} 
Aber die ihr den Staub nicht & Nie strząśnięcie z waszej & Ale którzy nie otrząsnęliście \\
von eurer Sehnsucht & tęsknoty & z waszej tęsknoty \\
Schütteltet, & Prochu, & Prochu, \\
Die ihr stehenbliebt, dort, & Zostaniecie tam, gdzie on \\
Wo er zu Licht & Którzy zatrzymaliście się \\
Verwandelt wird. & tam, gdzie on przemienia się \\
W światło. & W światło.
\end{tabular}

Jak widać, podstawowe różnice $\mathrm{w}$ przekładach tkwią głównie $\mathrm{w}$ zastosowanym czasie (na przykład „Nie strząśnięcie” u Herberta i „nie otrząsnęliście” u Krynickiego lub „Gdy [...] zrywacie fiołek” u Herberta / „Kiedy będziecie zrywać fiołek” u Krynickiego) oraz liczbie („waszym ciele” u Herberta / „swoim ciele” u Krynickiego czy „starego dębu” u autora Pana Cogito / „starych dębów” u autora Aktu urodzenia). W dalszej interpretacji korzystać będę dość swobodnie $\mathrm{z}$ obu tłumaczeń.

\section{Widzowie Zagłady}

Gdybym miał ten wiersz krótko i dość powierzchownie streścić, to powiedziałbym, że traktuje on o obserwatorach Zagłady. Właśnie obserwatorach, widzach (zuschauenden), a nie na przykład świadkach ${ }^{11}$. Ta różnica jest zasadnicza! Dobrze oddaje ją angielskie tłumaczenie. W tej edycji Ruth i Matthew Mead przełożyli tytuł jako You onlookers, a więc „Wy, spoglądający na” (on-lookers) ${ }^{12}$. Podkreśla to beznamiętność i ruch spojrzenia jakby od góry, spoglądania na rzecz, która jest poniżej (na przykład „na stół” czy „na krzesło”). Warto też zwrócić uwagę na formy gramatyczne. Tytuł w oryginale ma postać imiesłowu (Ihr Zuschauenden), którą należałoby przetłumaczyć dosłownie jako „wy spoglądający/wy przyglądający się". W obu polskich przekładach pojawia się rzeczow-

${ }^{11}$ Niezupełnie przekonuje mnie w tym kontekście propozycja Karoliny Koprowskiej, by ową kategorię oddać terminem "postronni” "Jako tłumaczenie angielskiego terminu bystander i jako alternatywne określenie świadka". Zob. K. Koprowska: Postronni? Zagłada w relacjach chłopskich świadków. Kraków 2018, s. 8. Autorka proponuje spojrzenie na postronnych przez pryzmat - przede wszystkim - psychologii społecznej, kategorii afektu oraz Lacanowskiej teorii transpasywności - obsceniczności, tj. odczuwania rozkoszy podczas "gapienia się na cudze cierpienie" (tamże, s. 44). W niniejszym tekście przyjmuję odmienną, filologiczną perspektywę, choć niektóre konstatacje, np. wskazywanie potrzeby „dekonstruowania bierności postronnych” (tamże, s. 31) lub wyparcie tego doświadczenia i przyjęcie rozmaitych strategii (prze)milczania owego doświadczenia, są mi również bliskie.

${ }_{12}$ Zob. N. Sachs: You onlookers. Transl. R. and M. Mead. In: N. Sachs: O the Chimneys..., s. 19. 
nik „widzowie”, co dodatkowo sprzyja zatuszowaniu aktywnej roli tych, którzy przyglądali się - a więc wykonywali jakieś działanie, nie byli całkiem bierni.

Semantyczną różnicę pomiędzy biernymi świadkami a aktywnymi widzami doskonale odzwierciedla również trzeciorzędny, choć z pewnych względów interesujący horror Zgromadzenie (2002) w reżyserii Briana Gilberta. Akcja filmu rozgrywa się we współczesnej Anglii. W Glastonbury dwójka młodych ludzi, uczestników festiwalu muzycznego, odłącza się od znajomych i wpada przypadkiem do rozpadliny w ziemi. Oboje giną, a odnalezieniu ich ciał towarzyszy odkrycie pod ziemią ruin najstarszej chrześcijańskiej budowli w Wielkiej Brytanii - kościoła romańskiego z I wieku, zbudowanego przez Józefa z Arymatei, naocznego świadka ukrzyżowania. Archeolodzy natrafiają na bardzo nietypową rzeźbę przedstawiającą krzyż. Podobizna Chrystusa wisi bowiem tyłem do wiernych, a centralne miejsce zajmuje skierowana do nich frontem płaskorzeźba prezentująca ludzi przyglądających się jego śmierci. Miejscowy ksiądz, w kluczowym dla mnie fragmencie filmu, chcąc wyjaśnić temat ołtarza, przytacza zagadkowy dotąd dla naukowców fragment listu Arystobulosa, rzekomego biskupa Brytów: „Przyszli tylko po to, by zobaczyć. Ze wschodu i zachodu, z miasta i równiny. Przyszli nie z pobożności, ale z powodu żądzy”. Jak tłumaczy ksiądz, w interpretacji płaskorzeźby nie jest istotny sam Chrystus, ale widzowie: „[...] zawsze byli ludzie, którzy przychodzili tylko dla widowiska. Robili na drutach koło gilotyny podczas rewolucji francuskiej, przyglądali się wieszaniu na szubienicy w Newgate, czekali na egzekucję na krześle elektrycznym"13. Wkrótce okazuje się, że postaci z płaskorzeźby widziane były w ciągu ostatnich 2000 lat wszędzie tam, gdzie działo się coś złego. Teraz pojawiają się ponownie. Tym, co warto z tego podrzędnego filmu zapamiętać, jest właśnie kwestia oglądania kaźni, problem gapiów czy widzów śmierci.

Zagadnienie to ma zresztą też poważniejszą wykładnię oraz starą, antyczną proweniencję. Dostrzegał je już bowiem Platon. W jednym z fragmentów Państwa poznajemy opowieść, która ma stanowić ilustrację do wywodu o rozgraniczeniu intelektu, pożądania i gniewu (jako czegoś przynależnego pożądaniu lub od niego oddzielonego). W historii tej:

Leontios, syn Aglajona, szedł raz z Pireusu na górę pod zewnętrzną stroną muru północnego i zobaczył trupy leżące koło domu kata. Więc równocześnie i zobaczyć je chciał, i brzydził się, i odwracał, i tak długo walczył z sobą i zasłaniał się, aż go żądza przemogła i wytrzeszczywszy oczy przybiegł do tych trupów i powiada: „No, macie teraz, wy moje oczy przeklęte, napaście się tym pięknym widokiem". [...]

To opowiadanie świadczy jednak - dodałem - że gniew czasem walczy z żądzami; widać, że jedno jest czymś innym i drugie. [...] kiedy żądze kogoś gwałtem

${ }^{13}$ Zgromadzenie. Reż. B. Gilbert. Scen. A. Horowitz. Wielka Brytania 2002, 0:36:080:37:03. 
przymuszają, wbrew rozsądkowi; wtedy on się gniewa na to, co w nim samym siedzi, a gwałt mu chce zadawać, i jak by się w nim walka odbywała, jego gniew przeciw temu czemuś zwrócony sprzymierza się z intelektem ${ }^{14}$.

$\mathrm{Z}$ podobnym problemem mamy do czynienia w utworze Sachs. Nie wiemy jednak, czy ci, „na oczach których zabijano”, trafili jako obserwatorzy w miejsce kaźni z własnej, nieprzymuszonej woli, powodowani głównie ciekawością. Wiemy jedynie, że nie podnieśli „morderczej ręki”, ale jednocześnie nie otrząsnęli z „tęsknoty prochu”. Już na zawsze zatrzymali się „tam, gdzie on przemienia się w światło". Uczestniczący w Zagładzie widzowie obarczeni zostają jakby zwrotnym „spojrzeniem umarłych”. W najbardziej tkliwych momentach swojego życia, kiedy będą zrywać fiołki i spacerować po lesie, ujrzą "gasnące oczy” oraz „błagalnie uniesione” ręce w „męczeńsko powykręcanych konarach”.

W niewielu miejscach Europy ów motyw spoglądania na zabijanie znajduje tak silny oddźwięk, jak w Polsce, gdzie Zagłada dokonywała się na oczach wszystkich. Niezależnie, czy mieszkali w mieście, czy (zwłaszcza!) na wsi. Każdy, kto miał sprawny zmysł powonienia i nieprzytępiony słuch, musiał słyszeć krzyki i czuć dym zamieniający ludzi w „proch”. Nawiasem mówiąc, ten sam obraz „morderczej dłoni” i dość zbliżona, poetycko-moralna dykcja (aczkolwiek zaczerpnięta, jak pamiętamy, przede wszystkim z wiersza Biedny chrześcijanin patrzy na getto Czesława Miłosza) pojawią się później, w 1987 roku, w eseju Jana Błońskiego Biedni Polacy patrza na getto ${ }^{15}$. Przywołuję go tutaj, ponieważ stał się jednym z ważniejszych tekstów poruszających problem polskiego „oglądania” Zagłady. Właśnie oglądania, ponieważ krytyk wskazywał na „współ-winę” (ale nie „współ-udział”!) Polaków, wzywał ich do „obowiązku zobaczenia naszej przeszłości w prawdzie”, do swoistego „moralnego przewrotu w stosunkach polsko-żydowskich"16. Na dobrą sprawę otworzył w naszym kraju debatę na temat odpowiedzialności po Holokauście ${ }^{17}$. Błoński stwierdzał w końcowym fragmencie: „Kiedy czyta się to, co o Żydach wypisywano przed wojną, kiedy się odkrywa, ile było w polskim społeczeństwie nienawiści - można się nieraz dziwić, że za słowami nie poszły czyny. Ale nie poszły (albo poszły rzadko). Bóg tę rękę zatrzymał [podkr. - B.K.]"18. Jak słusznie skomentował Piotr Forecki: „[...] negatywna odpowiedź na pytanie o współudział Polaków w Zagładzie

14 Platon: Państwo. Przeł. W. Witwicki. Ks. IV. Warszawa 1958, 439D-441B.

15 Zob. J. BŁoński: Biedni Polacy patrza na getto. „Tygodnik Powszechny” 1987, nr 2, s. 1, 4. Później esej został przedrukowany w książce pod tym samym tytułem (Kraków 1994; wyd. II 2008). Zob. też M. GŁowı́́ski: Esej Błońskiego po latach. „Zagłada Żydów. Studia i Materiały” 2006, nr 2.

16 J. BŁoński: Biedni Polacy..., s. 4.

17 Szerzej na temat eseju Błońskiego i okoliczności jego ukazania się piszę w książce Opowiedzieć Zagładę. Polska proza i historiografia wobec Holokaustu (1987-2003). Kraków 2013, tu rozdz. II Lata 1987-1989 - próba syntezy.

18 J. BŁoński: Biedni Polacy..., s. 4. 
była dlań równie kluczowa, jak i sama zarysowana przez Błońskiego koncepcja współ-winy"19. Jeszcze wyraźniej na ów problem jednoczesnego przekazywania wiedzy oraz czynienia jej niewidoczną, przełomu i natychmiastowego wyparcia wskazywał Tomasz Żukowski w szkicu Wytwarzanie „winy obojętności” oraz kategorii „obojętnego świadka” na przykładzie artykułu Jana Błońskiego „Biedni Polacy patrza na getto" ${ }^{\prime 20}$. W nawiązaniu do wydarzeń w Jedwabnem, Gniewczynie $^{21}$ czy w obliczu lektury akt procesów z tzw. dekretu PKWN z dnia 31 sierpnia 1944 roku („sierpniówek”) - wykorzystanych choćby przez zespół Barbary Engelking w głośnej publikacji Dalej jest noc... ${ }^{22}$ - oraz na podstawie własnych badań, w czasie których miałem do czynienia nie tylko z licznymi świadectwami wydawania, lecz również mordowania Żydów przez Polaków ${ }^{23}$, konstatacja Błońskiego nabiera gorzkiego wydźwięku i brzmi po prostu fałszywie. Często Bóg tej ręki jednak nie zatrzymywał.

Tymczasem u Sachs, tak jak u Błońskiego, znajdujemy frazę „Którzy nie podnieśliście morderczej ręki”. Jej wiersz to jednak nie tylko opis kondycji obserwatorów Zagłady, wyrzut sumienia i proste oskarżenie „podglądaczy”. Brzmi $\mathrm{w}$ nim także swoista nostalgia zamieniająca się w samooskarżenie. Kluczem do zrozumienia tego przedziwnego splotu wydaje się zastosowany przez poetkę język symboliczny, który nie poddaje się prostym, bezpośrednim odczytaniom. Ów język traktuję tu podobnie, jak czynił to Fromm w odniesieniu do snów, baśni i mitów. Niemiecki filozof i psycholog pisał:

Język symboliczny jest językiem, w którym wewnętrzne doświadczenia, uczucia i myśli wyrażamy tak, jak gdyby były doświadczeniami zmysłowymi, wydarzeniami z kręgu świata zewnętrznego. Jest to język, który rządzi się logiką różną od konwencjonalnej, stosowanej przez nas za dnia, logiką, w której nie czas i przestrzeń są kategoriami naczelnymi, lecz intensywność i kojarzenie ${ }^{24}$.

${ }_{19}$ P. Forecki: Od Shoah do strachu. Spory o polsko-żydowska przeszłość i pamięć w debatach publicznych. Poznań 2010, s. 154.

${ }^{20}$ Zob. T. Żuкowski: Wytwarzanie "winy obojętności” oraz kategorii "obojętnego świadka” na przykładzie artykułu Jana Błońskiego „Biedni Polacy patrza na getto”. „Studia Litteraria et Historica” 2013, nr 2, s. 423-451. Dostępne w Internecie: https://ispan.waw.pl/journals/index.php/ slh/article/view/slh.2013.018 [data dostępu: 20.10.2019].

${ }^{21}$ Nawiązuję tutaj do wstrząsającej relacji Tadeusza Markiela z historycznym komentarzem Aliny Sкibińskiej pt. „Jakie to ma znaczenie, czy zrobili to $z$ chciwości?”. Zagłada domu Trynczerów. Warszawa 2011.

${ }^{22}$ Zob. Dalej jest noc. Losy Żydów w wybranych powiatach okupowanej Polski. Red. B. ENGelking, J. Grabowski. T. 1-2. Warszawa 2018.

${ }^{23}$ Zob. np. B. KRupa: Powrót. Studium przypadku. „Studia Litteraria et Historica” 2018, nr 7. Dostępne w Internecie: https://ispan.waw.pl/journals/index.php/slh/article/view/slh.1731 [data dostępu: 20.10.2019].

${ }^{24}$ E. Fromm: Zapomniany język. Wstęp do rozumienia snów, baśni i mitów. Przeł. J. MarzęCKI. Wstęp K.T. Toeplitz. Warszawa 1972, s. 28-29. 
Co ważne, ów język ma „niejako własną gramatykę i składnięe”25, wymagającą raczej asocjacyjnego, mocno intuicyjnego niż dedukcyjno-logicznego podejścia. Przyjrzyjmy się zatem nieco dokładniej symbolom zawartym w $W y$, widzowie.

\section{Wprowadzenie do analizy. O języku Nelly Sachs}

Zanim przejdę do zasadniczej części tekstu, uczynić muszę jednak jeszcze dwa zastrzeżenia. Pierwsze dotyczy kwestii odniesienia niektórych metafor do całej twórczości autorki. Pewne obrazy i wątki stale się bowiem w jej wierszach przewijają. Poezja Sachs - jak słusznie zauważa Joanna Roszak - to swoiste „recydywy melancholijnych zawodzeń. Wracają w niej jak echo fluktuacje nastrojów, profuzja czarnych myśli" ${ }^{26}$. Dotyczy to również - a może zwłaszcza - metafor odnoszących się do Zagłady. Niektóre z tych emblematycznych odniesień pojawiają się też w Widzach - to przede wszystkim „proch”, lecz także „oko” czy „nocne nawoływanie”. Inne wskazuje Anna Zarawska:

Oprawca w utworach Nelly Sachs występuje więc pod postacią dłoni (Hände), palców (Finger) czy też zębów (Gebiss, Zähne). Spotykamy go także jako wędkarza (Angler), którego ofiarą jest ryba (Fisch) przedstawiana także jako skrzele (Kieme). Można tym sposobem wyszczególnić także inne pary: myśliwy (Jäger) i jego zwierzyna (Gejagte), prześladowca (Verfolger) i prześladowani (Verfolgte), natomiast siepacz (Häscher), kat (Henker), morderca (Mörder) czy grabieżca (Räuber) mają swoją ofiarę (Opfer). Ta ostatnia w poezji Nelly Sachs to także uciekinier (Flüchtling), dziecko (Kind), zakochani (Liebende), motyl (Schmetterling) i słowik (Nachtigall) oraz związane z nimi skrzydła (Flügel), gardło (Kehle). Z ofiarą wiążą się także pośrednio motyw dymu (Rauch), popiołu (Asche), prochu (Staub), piasku (Sand), stóp (Füße), butów (Schuhe) czy oka (Auge). Czas martyrologii i holocaustu to noc lub północ (Nacht, Mitternacht), panuje głucha cisza przerywana jedynie westchnieniem (Seufzer) lub krzykiem (Schrei) ${ }^{27}$.

Innymi słowy, dokonując interpretacji, nieustannie musimy pamiętać, że niektóre metafory są nieodłączną częścią całego imaginarium poetki, co wymagałoby innego typu analizy, uwzględniającej niejako całą jej twórczość. W szkicu tym koncentruję się tylko na jednym utworze.

Drugie zastrzeżenie dotyczy swoistej umowności poszukiwania wykładni symboliki liryków poetki. Zgadzam się bowiem z Zofią Zarębianką, która analizując wiersze $\mathrm{z}$ tomu Śmierć jeszcze świętuje życie, zauważyła, że

25 Tamże, s. 29.

${ }^{26}$ J. Roszak: Punkty, południki - poezja Nelly Sachs. „Topos” 2005, nr 3, s. 97.

27 A. Zarawska: Wyrazić niewyrażalne. Holocaust $w$ poezji Nelly Sachs. „Studia Niemcoznawcze” 2007, T. 34, s. 350 . 
oparta na skojarzeniach, nieraz dość odległych, struktura wewnętrzna tych utworów nie da się więc otworzyć przy pomocy racjonalistycznego klucza. Bardziej te wiersze czujemy, niż jesteśmy w stanie dokładnie powiedzieć, co znaczą poszczególne sformułowania i metafory... Wszystko bowiem dzieje się w tych tekstach na poziomie głębinowym i wyraża w niespójnym i niejako nieskładnym toku najbardziej wewnętrzne i pozapojęciowe doświadczenie rany ${ }^{28}$.

Zaszyfrowanie przekazu może być skutkiem czegoś, co Alvin H. Rosenfeld nazwał „poetyką ekspiracji”, a więc zapisu utraty tchu. Poezja, która do tej pory przywracała oddech dzięki inspiracji, po Zagładzie go raczej gubiła. Jak pisze Rosenfeld, Sachs odbywa drogę

w stronę ofiar, w stronę poezji, która w mimetycznych formach oddaje cząstkę nieopisywalnego horroru, jakim naznaczony był ich los. W ruchu w stronę milczenia, gdy język zarazem wyczerpuje się i odnawia, schodzą się w dziwaczny sposób siła i słabość poezji ${ }^{29}$.

Być może źródłem tej tajemniczości, owej mglistości języka symbolicznego jest również judaizm, za czym optuje, powołujący się na Meira Wienera, Marek Ostrowski:

[...] badacz kultury judaistycznej - Meir Wiener, wskazuje na typową cechę tej symboliki, jaką jest jej daleki od realności i nie zakorzeniony w codziennym doświadczeniu charakter, niejako odwrócenie od świata i brak pozorny celowości. Symbole mają ponadczasowy charakter, pozbawione są cech indywidualnych. Punktem odniesienia jest wyższa rzeczywistość pozbawiona cech ludzkich, wydarzenie z kręgu działań boskich ${ }^{30}$.

Splot ponadczasowości, języka niemieckiego, ikonoklazmu oraz rozsadzającej poetycką dykcję symboliki judaistycznej ${ }^{31}$, dzięki której do Sachs przylgnął przydomek „poetki żydowskiego losu” ${ }^{32}$, silnie upodabnia twórczość autorki Widzów

${ }^{28}$ Z. Zarębianka: Nelly Sachs: Cierpieć w czasie zabitym przez wieczność. „Topos” 2006, nr 5, s. 134.

${ }^{29}$ A.H. Rosenfeld: Podwójna śmierć. Rozważania o literaturze Holocaustu. Przeł. B. KRAWcowicz. Warszawa 2003, s. 136.

${ }^{30}$ M. Ostrowski: O liryce Nelly Sachs. „Filologia Germańska” [Piotrków Trybunalski] 2001, z. 2, s. 173 .

${ }^{31} \mathrm{Na}$ ten temat zob. np. W.A. Berendsohn: Nelly Sachs: Einführung in das Werk der Dichterin jüdischen Schicksals. Darmstadt 1974; G. Dischner: Die Lyrik von Nelly Sachs und ihr Bezug zur Bibel, zur Kabbala und zum Chassidismus. „Text+Kritik. Zeitschrift für Literatur“ 1969, Bd. 23: Nelly Sachs, s. 25-40. Sporo o mistycznej stronie jej twórczości i zanurzeniu w kabale pisze też Olof Lagercrantz w książce Versus über die Lyrik der Nelly Sachs. Berlin 1967.

${ }^{32}$ Zob. J. Szafarz: Nelly Sachs. Poetka żydowskiego losu. W: Niemieckojęzyczni laureaci literackiej Nagrody Nobla. Red. K. RuchniewicZ, M. Zybura. Wrocław 2006, s. 159-171. 
do poezji Paula Celana, z którym się zresztą przyjaźniła ${ }^{33}$. Oboje byli często porównywani. O obojgu niemieckojęzycznych twórcach da się także powiedzieć, za Pawłem Piszczatowskim, że przebywali w „atopicznych nie-miejscach utraconej obecności znaczeń i imion w świecie po Szoa", gdzie splata się mistyka i indywidualna pamięć o ofiarach Holokaustu ${ }^{34}$. Hans Magnus Enzensberger nazwał ich ostatnimi reprezentantami „niemieckiej poezji wysokiego tonu”35. Jak zauważa przywoływana już Roszak:

Jej poezja jawi się może jako mniej afatyczna i ekonomiczna, mniej zająkana, ale - podobnie jak Celanowska - rozgrzebująca blizny słów. Biegunowo - raz gojąca, raz rozdrapująca rany, z czasem coraz mroczniejsza. Stany psychiczne autorka Ciemnienia gwiazd odciskała w języku - wizjonerskim i mistycznym, znoszącym różnicę między życiem i śmiercią ${ }^{36}$.

Przejdźmy do baczniejszego przyjrzenia się samemu utworowi i zawartemu w nim szyfrogramowi.

\section{Symboliczna mowa Sachs}

Pierwsza strofa została już właściwie omówiona. Brzmi ona:

Unter deren Blicken getötet wurde.

Wie man auch einen Blick im Rücken fühlt,

So fühlt ihr an euerm Leibe

Die Blicke der Toten.

Opowiada ni mniej, ni więcej, tylko o fizycznym doświadczeniu powracającego „spojrzenia umarłych” wśród tych, którzy oglądali zabijanie. Wzrok zgładzonych przypomina „czyjeś spojrzenie na plecach”.

${ }^{33}$ Jak podaje Joanna Roszak: „Najintensywniejszy czas korespondowania autorów Znaków na piasku i Piasku z urn przypada na końcówkę lat 50. i początek 60. W 1960 dwa razy spotkali się osobiście. Od 25 do 27 maja spędzili czas w Zurychu. Poetycką relację z tej wizyty stanowi wiersz Zurych, Zum Storchen z Celanowskiego tomu Róża niczyja. Powstał on w Paryżu, cztery dni po rozmowie z Nelly Sachs, która miała miejsce 26 maja roku na werandzie hotelu Zum Storchen, usytuowanego nad brzegiem Jeziora Zuryskiego, w pobliżu romańskiej Katedry" (J. RoszaK: Punkty, południki..., s. 100).

${ }^{34}$ Zob. P. Piszczatowski: Znacze//nie wiersza. Apofazy Paula Celana. Warszawa 2014, cyt. za notką na okładce.

${ }^{35}$ Zob. H.M. Enzensberger: Droga Li... Rozmawiał J.S. Buras. „Literatura na Świecie” 1994, nr 6, s. 163.

${ }^{36}$ J. Roszak: Punkty, południki..., s. 96. 
Również o ostatniej strofie była już mowa. Brzmi ona następująco:

Ihr Zuschauenden,

Die ihr keine Mörderhand erhobt,

Aber die ihr den Staub nicht von eurer Sehnsucht

Schütteltet,

Die ihr stehenbliebt, dort, wo er zu Licht

Verwandelt wird.

Jak wiemy, ponownie pojawiają się $\mathrm{w}$ niej ci, którzy z jednej strony nie podnieśli „morderczej ręki”, z drugiej „nie otrząsnęli” ze swojej tęsknoty prochu („Aber die ihr den Staub nicht von eurer Sehnsucht Schütteltet”). Ów proch (Staub), a właściwie kurz czy pył (w znaczeniu angielskiego dust, a nie powder), może nawet popiół (der Asche, ang. ashes), to - jak pisałem - znana w twórczości poetki, szczególnie w tym pierwszym tomie, metafora konotująca Zagładę i jej ofiary. Juan-Eduardo Cirlot zauważa, że proch powstaje w procesie rozpadu minerału. To znaczy wtedy, kiedy osiąga on stan maksymalnej, dostrzegalnej jeszcze destrukcji, najniższej - według ludzkiej miary - formy rzeczywistości ${ }^{37}$. Dlatego proch, podobnie jak popiół (choć ten ostatni łączy się z ogniem, proch zaś z ziemią), ma sens negatywny, związany ze śmiercią. Następnym etapem, już na granicy widzialności, będzie moment, w którym proch „przemienia się w światło”, a ściślej „w światło przeistacza się”, poetka zastosowała bowiem przerzutnię (podobnie jak w poprzednim wersie, gdzie „przerzucony” został inny czasownik - strząsać). Jest to miejsce, gdzie zatrzymali się widzowie i gdzie kończy się również wiersz.

Interesujące rzeczy dzieją się w strofach drugiej i trzeciej. Pozostając przy tym niechronologicznym, podążającym za wykładnią symboliczną układzie interpretacji, przyjrzę się najpierw strofie trzeciej:

$\mathrm{O}$ die ungesungenen Wiegenlieder

In der Turteltaube Nachtruf -

Manch einer hätte Sterne herunterholen können,

Nun muss es der alte Brunnen für ihn tun!

Czym są owe „niezaśpiewane kołysanki w nocnym nawoływaniu turkawki”? Noc, jak pisałem, to często czas Zagłady. Tutaj przerwana zostaje kołysanką. A właściwie nieprzerywana, są to wszakże kołysanki „niezaśpiewane” lub - jak chce Herbert - „niewyśpiewane”. Wykrzyknienie „O”, które otwiera tę strofę, sugeruje, że podmiot liryczny tęskni za nimi, chciałby, żeby noc się skończyła. Przywołanie kołysanek stanowi zatem świadectwo jego nostalgii.

37 Zob. J.-E. Cirlot: Słownik symboli. Przeł. I. Kania. Kraków 2000, s. 330. 
Nieco zagadkowe jest wykorzystanie metafory turkawki (Tureltaube). Obecność stworzeń latających w poezji Sachs wymagałaby zresztą oddzielnego omówienia. Tutaj zauważę tylko, znów za Cirlotem, że ptak ten symbolizuje wierność i czułość między ludźmi. Występuje w wielu alegoriach, ale bywa często mylony z gołębicą ${ }^{38}$. Pojawia się choćby w sonecie Szekspira Feniks i gołąb, o którym Leslie Dunton-Downer i Alan Riding piszą, że jest jego „najbardziej zagadkowym utworem"39. Choć wiersz składa się z zaledwie 67 wersów - na poły ułożonych kwartynami, na poły, w części będącej trenem, tercetami - odczytuje się go jako mroczną, hipnotyzującą wręcz łamigłówkę, której mistrzostwo polega na braku rozwiązania. Na przykład Witold Chwalewik uważa, że Szekspirowski poemat „stanowi dla krytyki nierozwikłaną zagadkę"40. Nie ma jednak raczej wątpliwości, że głównym tematem utworu jest miłośćc ${ }^{41}$.

Kochali się, jedna była

Istota miłości dwojga;

Jedność żyła wśród obojga:

Ich miłość liczbę zabiła ${ }^{42}$.

Co ciekawe, Feniksa i gołębia uznano za ważny liryk dopiero w epoce modernizmu, kiedy to bogactwo języka i przejmująca melodyka zapewniły mu status arcydzieła. W angielskim oryginale mowa jest jednak nie o gołębiu (pigeon),

38 Zob. tamże, s. 429.

39 L. Dunton-Downer, A. Riding: Szekspir. Przeł. D. Koper, R. Morusiewicz. Warszawa 2005.

40 W. ChWAlewik: Z literatury angielskiej. Studia i wrażenia. Warszawa 1969. Jednocześnie badacz nie poddaje się, próbując zgłębić tajemnicę sonetu, i stawia hipotezę, że źródłem poematu jest inny utwór, autorstwa normandzkiego truwera Guillaume’a de Normandie, Le Bestiaire divin, datowany na ok. 1208 r. Interpretacja ta zakłada, rzecz jasna, że autor Makbeta doskonale znał język francuski.

${ }^{41} \mathrm{~W}$ interpretacji Jerzego Strzetelskiego: „Ogromna miłość niezwykłej królewskiej samicy i tradycyjnie wiernego samca (!) jest platoniczna: odległość między kochankami uniemożliwiła im posiadanie potomstwa i oto teraz oba ptaki są nieżywe, a dla świata nic po nich nie pozostało. W innych wierszach o tych szlachetnych ptakach idealizm platoński występuje silniej: Feniks odrodzi się z popiołów. U Shakespeare’a wiary w odrodzenie nie ma, jest za to wiele szczerego żalu. Jak wszystkie dzieła Shakespeare’a, tak i to obrosło w najróżniejsze interpretacje. Uważane było za alegorię miłości hrabiego Essexa i królowej Elżbiety I, Shakespeare’a i hrabiego Southampton, za alegorię stosunku artysty do swej sztuki, ciała i duszy, itd. Najprawdopodobniejsza jest pierwsza interpretacja. Zwolennicy Essexa, do których zapewne należał i Shakespeare, chcieli przedstawić hrabiego jako śmiertelnie zakochanego w królowej, a jego błędy, wynikające z porywczej i nierozważnej natury - za postępki niezwykłego kochanka. Niestety, w czasie kompilowania tomiku Essex został uwięziony i stracony. Stąd niekonsekwencje. Wiersz pozostaje zatem enigmatyczny, potrafi jednak przemawiać po prostu, łagodnym tonem, lecz z niezachwianą wiarą w prawdziwą miłość” (J. Strzetelski: Posłowie. W: W. Shakespeare: Wiersze i poematy. Przeł. M. SŁOMCZYŃSKi. Kraków 1977, s. 263-264).

42 W. Shakespeare: Feniks i Turkawka. W: W. Shakespeare: Wiersze i poematy..., s. 191. 
a właśnie o turkawce (turtledove). Tytuł The Phoenix and Turtle, który może być również źródłem nieporozumien' ${ }^{43}$, został zresztą dodany przez późniejszych wydawcó ${ }^{44}$. Dokładny polski przekład tytułu zawdzięczamy, skądinąd często nieprecyzyjnemu, Maciejowi Słomczyńskiemu, który zbytnio nie cenił Szekspirowskich wierszy ${ }^{45}$.

Wracając do Widzów: turkawka - symbol miłości - swoim nocnym nawoływaniem nie zmieni jednak milczenia nocy w kołysankę. Niewiele brakowało. W wersji Herberta: „jeszcze jeden jej głos mógłby ściągnąć gwiazdę” (u Krynickiego: „Niejeden mógłby ściągnąć na dół gwiazdy”). Tak się jednak nie stało, „teraz musi to uczynić stara studnia”. Tym, co pozostaje i niesie ratunek, jest więc studnia - a właściwie „stara studnia”, der alte Brunnen (w tym wierszu stare, alt, są też dęby, ale o tym za chwilę) - ściągająca na dół gwiazdy (lub "gwiazdę", jak chce Herbert).

Cóż za osobliwy obraz. Nienowy jednak. Studnia i gwiazda pojawiają się choćby na siedemnastym arcanum tarota. Widzimy na nim nagą kobietę przy studni ( $w$ innych wersjach nad sadzawką), która $\mathrm{z}$ jednego dzbana wylewa wodę do niej, a z drugiego na ziemię. Nad nią zaś świeci wielka gwiazda. Karta symbolizuje młodość i dorastanie, a także rozwój duchowy. W położeniu prostym oznacza ład i harmonię wewnętrzną, dorastanie w niewinności, jak również spotkanie właściwego partnera życiowego. Z kolei w położeniu odwróconym konotuje ona niepokój i nieudane życie uczuciowe. Cirlot twierdzi:

Ostateczny sens symboliczny tego obrazu zdaje się wyrażać komunikację między światami, ożywianie przez świecące ciała niebieskie płynów zawartych w zbiornikach i przekazywanie tych jakości czysto materialnym ziemi i wodzie. Dlatego Oswald Wirth stwierdza, że arcanum to przedstawia duszę wiążącą ducha z materią ${ }^{46}$.

${ }^{43}$ Turtle po angielsku to także „żółw”, stąd często mylnie tłumaczono tytuł utworu.

${ }^{44}$ Jak pisze Jerzy Strzetelski, poemat „jest jednym z kilku utworów zebranych w dosyć dziwnym tomie wierszy z $1601 \mathrm{r}$. Na końcu chaotycznego poematu o Feniksie, napisanego przez trzeciorzędnego poetę Roberta Chestera, znalazło się sześć wierszy na ten sam temat, pióra Shakespeare'a, Johna Marstona, George'a Champana i Bena Johnsona - sławnych pisarzy owego czasu, oraz dwóch anonimowych poetów" (J. Strzetelski: Posłowie..., s. 263).

${ }^{45}$ Maciej Słomczyński był bardzo surowy wobec Szekspirowskiej poezji. Pisał: „Nie lubię po prostu tej produkcji, bo odstręcza mnie jej polerowana płynność i nieszczerość [...] próbując obiektywizować przyznać trzeba, że obok wielu prześlicznych sonetów istnieje w owym zbiorze co najmniej kilkadziesiąt nędznych wierszyków: banalnych, nieodkrywczych, ckliwych, zaopatrzonych w konwencjonalne, ograne chwyty poetyckie, obciążonych rozgadaniem i płaską dydaktyką" (M. SŁomczyński: Od tłumacza. W: W. Shakespeare: Wiersze i poematy..., s. 255).

${ }^{46}$ J.-E. Cirlot: Słownik symboli..., s. 154. Nawiasem mówiąc, tytuł 17 arcanum (1944) nosi również powieść André Bretona, w swoim czasie uważana za bardzo radykalną. U jej genezy leżały poznanie 10 grudnia 1943 r. Élisy Claro, trzeciej żony, oraz wydarzenia wojenne (szczególnie miesiące po lądowaniu aliantów w Normandii). W 1944 r. Breton i Claro podróżowali razem przez półwysep Gaspésie na południowo-wschodnich krańcach Québecu. Pisarz uczynił z oglą- 
Sama studnia, zdaniem Władysława Kopalińskiego, symbolizuje „moce twórcze, tajemnicę, pułapkę; prawdę, wyrocznię; koronę, władzę królewską; chrzest, duchy opiekuńcze, błogosławieństwo, pielgrzymkę, drabinę zbawienia, wieczność, Raj; życie, wodę żywą, napój życia i rady; duszę, człowieka, młodość, miłość, zasadę żeńską; mikrokosmos, podświadomość, oczyszczenie, odrodzenie, pragnienie, pokrzepienie, uzdrowienie, spełnienie życzeń, obfitość" ${ }^{47}$. Jest także studnia (zwłaszcza w Biblii) miejscem spotkań - sługi Abrahama z Rebeką (Rdz 24,15-21), Jakuba z Rachelą (Rdz 29,1-12) czy Mojżesza z siedmioma córkami Jethry Raguela, kapłana midianickiego (Wj 2,15-22). Religijne, ocalające odniesienia są tu bardzo ważne. Jak podkreśla Cirlot:

W kontekście symboliki chrześcijańskiej, w grupie koncepcji zogniskowanych wokół pojęcia życia jako pielgrzymowania, studnia oznacza zbawienie. Jako źródło odświeżającej i oczyszczającej wody jest ona symbolem wzniosłych aspiracji, „srebrnego sznura” łączącego człowieka z centralnym pałacem. Stąd symboliczne odnajdywanie studni jest znakiem zapowiadającym sublimację. Demeter i inne bóstwa wyobrażono jako stojące obok studni. Symbol ten występuje nie tylko w wyższych kulturach antyku, ale również wśród ludów pierwotnych. Schneider wskazuje, że wśród ludów animistycznych ośrodkiem obrzędów leczniczych jest sadzawka lub studnia, której wodą chorzy zwilżają sobie ręce, pierś i głowę. Na brzegu leżą muszle i rosną trzciny, oznaczające wodę zbawienia. W szczególności czerpanie wody ze studni jest, podobnie jak łowienie ryb, wydobywaniem czegoś z głębi; tym, co wychodzi na powierzchnię, jest jakaś treść numinalna. Przyglądanie się wodzie w jeziorze lub studni oznacza postawę mistyczno-kontemplacyjną. Studnia jest również, już w alegoriach i emblematach średniowiecznych, symbolem animy i atrybutem żeńskim $^{48}$.

Studnia zatem ratuje. W przypadku tego wiersza - gwiazdę/gwiazdy, a więc obraz idei boskiej, światła, wiedzy o przeszłości, teraźniejszości i przyszłości, losu, doli, przeznaczenia, duszy, ożywionych duchów, nieśmiertelności, natchnienia poetyckiego ${ }^{49}$. Warto też zauważyć, że gwiazda odgrywa niepoślednią rolę w judaizmie. Ostrowski pisze:

danej tam Percé Rock centralną metaforę dla powieści, w której przeplatały się miłość i strata, wojna i pacyfizm, feminizm i okultyzm. Arcane 17 składa się zarówno z fragmentów prozatorskich, jak i poetyckich. Jest po części zapisem realności, po części snów. Jak mówił autor, powieść zrodziła się z „potrzeby napisania książki związanej z Gwiazdą tarota, z panią, którą kocham, jako modelem". Breton pisze o tym w liście skierowanym 8 marca 1944 r. do Patricka Waldberga. Cyt. za: H. D’Étienne-Alain: Notice. In: A. Breton: Des cuvres complètes. T. 3. Paris 1999, s. 1164.

47 W. Kopaliński: Stownik symboli. Warszawa 2001, s. 408-409.

${ }^{48}$ J.-E. Cirlot: Stownik symboli..., s. 389.

${ }^{49}$ Zob. W. Kopaliński: Stownik symboli..., s. 101. 
Według nauki mistycznej siła światła gwiazd świadczy o ich współistotności z płynącą od Boga jakością. Gwiazda jest więc w kabale symbolem boskiej bliskości, przedsionkiem Boga. W pozytywnym przedstawieniu gwiazd powinno być widoczne pragnienie wzniesienia się, chęć doskonałości ${ }^{50}$.

W innym utworze tomu In den Wohnungen des Todes - Qual, Zeitmesser eines fremden Sterns (Męka, czasomierz obcej gwiazdy), poprzedzonym zresztą cytatem z Księgi Blasku (Zohar): „Szaty poranka nie są szatami wieczoru”51, poznajemy jeszcze inne znaczenie gwiazdy, w tym przypadku „obcej”. Jej czasomierz wyznacza mękę. Gwiazdę umieści też poetka w tytule następnego zbioru, poświęconego nieżyjącemu ojcu - Sternverdunklung („Zaćmienie gwiazdy”) z 1947 roku $^{52}$. Jednak wbrew opinii Ostrowskiego, że „wiersze Nelly Sachs są utworami wynikającymi bez wątpienia z poczucia egzystencjalnego zagrożenia”, zaś „obecny w nich pierwiastek mistyczny utracił swój budujący pozytywny impuls"53, w Widzach gwiazda zostaje jednak uratowana ${ }^{54}$. Właśnie przez „starą studnię”.

Warto także zauważyć obecność myślnika przepoławiającego trzecią strofę. Akurat w przypadku Widzów poetka operowała tym znakiem interpunkcyjnym wyjątkowo oszczędnie - zastosowała go tylko raz. Zupełnie inaczej ma się sprawa z innymi wierszami z tego i pozostałych tomików, które pełne są przeróżnych myślników i dywizów ${ }^{55}$. Znaki te stają się często u Sachs miejscem niedookreślenia, jako że nie ma jasnych przepisów dotyczących ich stosowania, w odróżnieniu na przykład od przecinków, co podkreślał Jürgen Stenzel ${ }^{56}$. W twórczości Sachs szczególną funkcję pełnią myślniki na końcu utworów. Jak zauważyła Gisela

${ }^{50}$ M. Ostrowski: O liryce Nelly Sachs..., s. 176.

${ }^{51}$ N. Sachs: Męka, czasomierz obcej gwiazdy. Przeł. R. Krynicki. W: N. SAchs: Rozżarzone zagadki..., s. 19.

${ }^{52} \mathrm{Na}$ temat motywów astralnych w twórczości poetki zob. W. Grothe: Astralmotive im Universum der Nelly Sachs. „Text+Kritik. Zeitschrift für Literatur“1969, Bd. 23: Nelly Sachs, s. 13-24.

53 M. Ostrowski: O liryce Nelly Sachs..., s. 176 i 178.

54 Istnieje też ironiczny rewers historii gwiazdy. „Stern” to tabloidowy tygodnik niemiecki, który ukazuje się od sierpnia 1948 r. w Hamburgu, obecnie (dane na 2014 r.) wychodzi w nakładzie ok. 750 tys. egzemplarzy. W 1983 r. wybuchła głośna afera dotycząca dziennika Adolfa Hitlera (62 tomy), którego fragmenty po raz pierwszy, w numerze z 28 kwietnia, opublikował właśnie „Stern”. Wkrótce okazało się, że dziennik Hitlera sprokurował Konrad Kujau - redaktor czasopisma, co doprowadziło do międzynarodowego skandalu oraz zwolnienia sporej części redakcji. Mimo wyraźnego kryzysu pismo istnieje do dzisiaj. Zob. F. Esser, U. Hartung: Nazis, Pollution, and no Sex. Political Scandals as a Reflection of Political Culture in Germany. "American Behavioral Scientist” 2004, no 47 (8), s. 1040-1071.

55 Szerzej na temat myślników w twórczości Ingeborg Bachmann, Paula Celana i właśnie Nelly Sachs pisała Ulrike Vedder. Zob. TAż: „Verhoffen“: Gedankenstriche in der Lyrik von Ingeborg Bachmann, Nelly Sachs und Paul Celan. In: Die Poesie der Zeichensetzung. Studien zur Stilistik Der Interpunktion. Hrsg. A. Nebrig, C. Spoerhase. Berno 2012.

56 Por. J. Stenzel: Zeichensetzung. Stiluntersuchungen an deutscher Prosadichtung. Göttingen 1966, s. 7-21. 
Bezzel-Dischner - oddziałują one poza tekst, jakby „nie dało się dalej mówić, ponieważ »brakuje słów«, są zbyt potworne, nie-wypowiadalne" ${ }^{\text {" }}$. Przykładem może być liryk Koniec (Ende) z tomu Ucieczka i przemiana (Flucht und Verwandlung; 1959), który na przekór tytułowi właśnie nie ma końca, ponieważ słowo staje się ciałem przesianym „w spragniony piasek -" 58 i tutaj utwór wprowadza znak ciągłości, jednocześnie się urywając. Zapytana kiedyś o dużą liczbę myślników w swej poezji Sachs odpowiedziała z wdziękiem: „To dlatego, że nigdy nie nauczyłam się interpunkcji”"59.

Wróćmy jednak do analizy symboliki zawartej w Widzach. Celowo zakłóciłem nieco kolejność i zachowałem na koniec dwa symbole ze strofy drugiej, które z różnych względów wydają mi się kluczowe. Chodzi o fiołek i dąb.

\section{Fiołek i dąb}

Przypomnę, w strofie drugiej podmiot wylicza, każdorazowo z zastosowaniem anafory „Ile” (Wievel), co i w jakich miejscach widzów nawiedzi:

Wieviel brechende Augen werden euch ansehn

Wenn ihr aus den Verstecken ein Veilchen pflückt?

Wieviel flehend erhobene Hände

In dem märtyrerhaft geschlungenen Gezweige

Der al ten Eichen?

Wieviel Erinnerung wachst im Blute

Der Abendsonne?

Gasnące oczy pojawią się podczas ukradkowego zrywania fiołków, błagalnie uniesione ręce w "powykręcanych konarach” („splątanych gałęziach” u Herberta) starych dębów, wspomnienia zaś w „krwi zachodzącego słońca”.

Skąd wzięły się te obrazy? Dlaczego widzom Zagłady poetka kazała zrywać fiołki? Kwiaty te, jak podaje Kopaliński, symbolizują „niewinność, cnotę, pokorę, skromność; prawdę, tajemnicę; stałość w uczuciach, wierność, miłość, szczęście; namiętność; szczerość; zadumę”, lecz także „cierpienie; przemijanie, krótkotrwałość, żałobę" ${ }^{\text {"60 }}$. Przede wszystkim jednak są delikatnym wyrazem miłości dziecka do matki czy narzeczonego do narzeczonej.

${ }^{57}$ G. Bezzel-Dischner: Poetik des modernen Gedichts. Zur Lyrik von Nelly Sachs. Bad Homburg 1970, s. 21.

${ }^{58}$ N. Sachs: Koniec. Przeł. R. Krynicki. W: N. Sachs: Rozżarzone zagadki..., s. 99.

${ }^{59}$ Cyt. za: A. Fionetos: Flucht und Verwandlung. Nelly Sachs, Schriftstellerin, Berlin/Stockholm. Berlin 2010, s. 279.

${ }^{60}$ W. Kopaliński: Słownik symboli..., s. 90. Jako symbol nietrwałości lub żałoby pojawia się fiołek przede wszystkim w utworach Szekspira („Fiołek młodocianej wiosny, wczesny, lecz wątły, 
Co ważne, fiołek jest kwiatem trwale obecnym w niemieckiej poezji. Za sprawą wiersza Goethego Fiołek (Das Veilchen) został on unieśmiertelniony jako symbol ofiary poniesionej z miłości. W balladzie Goethego znajdujemy też tak charakterystyczne dla poezji Sachs wykrzyknienie lub westchnienie „O”:

Maleńki fiołek w trawie kwitł:

Nikt go nie kochał, nie znał nikt...

A wdzięczny był to fiołek!

Pasterkę kiedyś dojrzał on,

Jak - piękna, hoża - szła przez błoń

I śpiew i śpiew

Wesoły wiodła śpiew!

- O - westchnął fiołek - gdybym tak

Był kwiatów najpiękniejszy kwiat,

Nie taki marny fiołek,

To by nie mogła obok przejść:

Zerwała - wzięłaby na pierś -

I z nią i z Nią

Choć chwilkę byłbym z Nią!

Ona już blisko... blisko tak!

Lecz, ach! - nie widząc - depcze kwiat:

Chyli się biedny fiołek...

Lecz kona, dzięki przecież śląc:

$\mathrm{O}$, ginę, jednak ginę choć

Od stóp, od stóp,

Od Twoich przecie stóp!... ${ }^{61}$

Sachs, co podkreślają krytycy, niewątpliwie nawiązywała do tradycji romantyzmu ${ }^{62}$. Dokonując próby interpretacji jej języka symbolicznego, szukam przede wszystkim wśród tekstów, które poetka mogła znać, które ją mogły uformować. Niewątpliwie w polskim kręgu językowym, do którego autorka nie

luby, lecz nietrwały, woń, tylko kilka chwil upajająca, nic więcej”; fiołek to kwiat żałobny, nagrobny: „Spuście ją [tj. Ofelię - B.K.] do grobu, niechaj z tych pięknych, nieskalanych szczątków fiołki wykwitną!” (W. Szekspir: Hamlet. Przeł. J. Paszkowski. W: W. Szekspir: Dzieła dramatyczne. Oprac. S. Helsztý́ski, R. JabŁkowska. T. 6: Tragedie. Warszawa 1958, s. 25-26 i 141)).

${ }^{61}$ J.W. Goethe: Fiołek. Przeł. S. Zarębski. W: J.W. Goethe: Wybór poezji. Oprac. Z. CieCHAnowsKa. Wrocław 1955, s. 80-82. Wiersz przekładali także m.in.: Bruno Kiciński, Antoni Odyniec, Ludwik Jenike, Wiktor Baworowski czy Andrzej Lam. Utwór stanowił część napisanego przez poetę libretta operetki Erwin und Elmire. Do jego słów powstała również kompozycja Mozarta (1785). Interpretowali go też muzycznie Philipp Christoph Kayser, Johann Friedrich Reichardt i Stanisław Moniuszko.

${ }^{62}$ Skądinąd wiemy także, że w młodości Sachs uczęszczała na wykłady Maxa Herrmanna znawcy romantyzmu i twórcy teatrologii. Zob. J. SzAfarz: Nelly Sachs..., s. 163. 
należała, ważne miejsce zajmują w tym kontekście późnoromantyczne wiersze Gustawa Zielińskiego (1809-1881), rówieśnika Słowackiego, reprezentanta tzw. ukraińskiej szkoły poetów ${ }^{63}$, utwory, w których znaleźć możemy fiołek - symbol miłości, w dodatku kwitnący „w ukryciu”. Pierwszy młodzieńczy tekst nosi wymowny tytuł Tulipan i fiołek (1832). Tulipan symbolizuje w nim pychę, fiołek skromność:

Pycha, próżność, balsk zwodniczy -

Tulipan, w społecznem życiu;

Fiołek, skromność, cnoty liczy -

Fiołek znajdziesz, lecz w ukryciu ${ }^{64}$.

Drugi wiersz, dwa lata późniejszy, napisany w roku zesłania poety na Syberię, nosi tytuł Miłość (1834). Przytoczę go w całości:

„Czy wiesz, co to miłość?” - „Miłość, mój kochanku,

Dwóch serc harmonja, pierwszy uśmiech w życiu,

Słońce wschodzące w dni naszych poranku,

Fiołek kwitnący w ukryciu”

„O! moja luba, to nie znasz miłości;

Miłość w tem życiu, krótka złudzeń chwilka,

Jeden sen piękny na kwiatach młodości,

Bóstwo, na skrzydłach motylka"65.

Przede wszystkim zaś warto przypomnieć Jak... Norwida, utwór rozpoczynający się słowami: „Jak gdy kto ciśnie w oczy człowiekowi / Garścią fiołków i nic mu nie powie..." ${ }^{\prime 66}$, w którym również pojawiają się księżyc i ptaki (jaskółki) ${ }^{67}$.

${ }^{63}$ Zob. „Szkoła ukraińska” w romantyzmie polskim. Szkice polsko-ukraińskie. Red. M. NEsteruk, S. Makowski, U. Makowska. Warszawa 2013. Na temat Zielińskiego zob. np. Gustaw Zieliński. Życie i dzieło. Red. M. Krajewski. Rypin 1988 oraz A.M. Stogowska: Wpisany w epokę: Gustaw Zieliński (1809-1881). Płock 1996. Na marginesie warto dodać, że w romantycznych poezjach Zielińskiego również bardzo często pojawia się charakterystyczne dla Sachs wykrzyknienie „O!”, by wymienić tylko Pożegnanie: „O! nie raz pierwszy w mojem życiu całem”, czy Dwa sonety (na śmierć brata): „O! tajniki serc naszych...” (w: Poezye Gustawa Zielińskiego. Wydanie zupełne poprzedzone życiorysem na podstawie listów poety skreślonym i ocena jego działalności przez dr. Piotra Chmielowskiego. Toruń 1901, s. 231 i 251).

${ }^{64}$ G. Zieliński: Tulipan i fiołek. W: Poezye Gustawa Zielińskiego..., s. 235-236.

${ }^{65}$ G. Zieliński: Miłość. W: Poezye Gustawa Zielińskiego..., s. 262.

${ }^{66}$ C. Norwid: Jak gdy kto ciśnie w oczy człowiekowi. W: Tenże: Pisma wszystkie. Zebrał, tekst ustalił, wstępem i uwagami krytycznymi opatrzył J.W. Gomulicki. T. 2: Wiersze. Cz. 2. Warszawa 1971, s. 82-83. Pierwotnie utwór wchodził zapewne w skład Vade-mecum, ale ostatecznie został pominięty w autografie. Na ten temat zob.: C. Norwid: Vade-mecum. Oprac. J. Fert. Wrocław-Warszawa-Kraków-Gdańsk-Łódź 1990, s. CXIV-CXV.

${ }^{67} \mathrm{Za}$ przypomnienie tego wiersza serdecznie dziękuję dr Anicie Jarzynie. 
Jeszcze trwalej niż fiołek z romantyzmem i kulturą niemiecką związany jest dąb, w którego „powykręcanych konarach” widzowie śmierci zobaczyć mają „błagalnie wyciągnięte ręce”. Dąb, nieodłącznie kojarzony z siłą i trwaniem, to symbol drzwi do nieba, świętości, wytrzymałości, długowieczności, siły fizycznej, majestatu i triumfu, lecz także grzmotu i ognia. Jak pisze przywoływany już wielokrotnie Cirlot:

W całym świecie aryjskim - od Rosji przez Germanię i Grecję aż do Skandynawii - dąb miał to samo znaczenie symboliczne i alegoryczne. Drzewo związane z kultem Jowisza, czczone przez Germanów i poświęcone Donarowi, bogu grzmotu. Odnośnie do pioruna zauważmy, że jest on poniekąd aspektem odwrotnym drzewa i jego odpowiednikiem, oba bowiem mają związek z osią świata i zjednoczeniem nieba z ziemią ${ }^{68}$.

Na pragermańską genezę symboliki dębu wskazuje też Kopaliński:

Skandynawowie odbywali zgromadzenia wolnych mężczyzn (thing, ting) pod dębami, w których mieszkać miały dusze przodków, udzielające zebranym swego doświadczenia i dobrych rad. Było to także ulubione miejsce spotkań czarodziejów i wróżek ${ }^{69}$.

Nic więc dziwnego, że drzewo to darzyli wyjątkową estymą nawiązujący do tej tradycji naziści ${ }^{70}$. Jak zauważa Rosa Sala Rose w Krytycznym słowniku mitów i symboli nazizmu:

Już emblemat stowarzyszenia Thule przedstawiał dwie gałęzie dębu skrzyżowane nad rękojeścią miecza; także swastykę, którą trzymał w szponach nazistowski orzeł, otaczał dębowy wieniec. Albert Speer stwierdza, że w okresie Trzeciej Rzeszy planowano zakładanie w miastach alei dębowych; miały się tam znajdować budowle o charakterze świeckim przeznaczone na uroczystości odprawiane dla uczczenia zwycięstw lub w hołdzie bohaterom ${ }^{71}$.

${ }^{68}$ J.-E. CirLot: Stownik symboli..., s. 108.

${ }^{69}$ W. Kopaliński: Słownik symboli..., s. 59.

${ }^{70}$ Jednym z najsłynniejszych niemieckich dębów był tzw. dąb Goethego, rosnący na zboczu Ettersbergu, niedaleko Weimaru. Miał ponoć pod nim siadać ojciec niemieckiego romantyzmu. W latach 30. drzewo znalazło się na terenie założonego tam obozu w Buchenwaldzie. Wieszano na nim więźniów politycznych i świadków Jehowy. Podczas nalotu alianckiego w sierpniu $1944 \mathrm{r}$. dąb spłonął, pozostał po nim jedynie pień. Szerzej o „dębie Goethego” i jego roli w relacjach więźniów pisze Magdalena SACHA. Zob. TAż: Dąb Goethego czyli o ochronie pomników przyrody w III Rzeszy. W: Poszukiwanie sensów. Lekcja z czytania kultury. Red. P. Kowalski, Z. Libera. Kraków 2006, s. 197-222.

${ }^{71}$ R.S. Rose: Krytyczny słownik mitów i symboli nazizmu. Przeł. Z. Jakubowska, A. RURARZ. Warszawa 2006, s. 65. 
Kulminację nazistowski kult dębu osiągnął na pamiętnych igrzyskach olimpijskich w Berlinie w 1936 roku. Wieńce z liści tego drzewa zastąpiły tradycyjne - laurowe i oliwne. Zwycięzcy olimpijczycy otrzymywali też sadzonkę dębu w doniczce ozdobionej napisem: „Rośnij na chwałę zwycięzcy i głoś przyszłe czyny"72.

Potwierdzenie romantyczno-niemieckiej, symbolicznej proweniencji obu roślin - fiołka i dębu - znajdujemy także dość zaskakująco w niemiecko-amerykańsko-izraelskim filmie Zmartwychwstanie Adama (2008), w reżyserii Paula Schradera, z Jeffem Goldblumem w tytułowej roli Adama Steina. Obraz otwiera nostalgiczne zdanie bohatera, któremu towarzyszą retrospektywne, czarno-białe migawki z okresu międzywojennego: „Miałem kiedyś piękną ojczyznę. Dęby rosły tam wysoko, fiołki drżały delikatnie. Kraj ten był snem. Całował mnie po niemiecku, szeptał po niemiecku. Trudno uwierzyć jak słodko brzmiało: Ich liebe dich - kocham cię"73.

Film Schradera jest adaptacją głośnej i bodaj najlepszej powieści z bogatej przecież twórczości Jorama Kaniuka - Adam, syn psa z 1969 roku $^{74}$. Książka (i film) opowiada historię mieszkańca Berlina, przed wojną klauna i właściciela cyrku, który stał się świadkiem śmierci żony i córki w obozie. Udało mu się przetrwać tylko dlatego, że jego występy przypomniał sobie komendant Klein (w filmie doskonały Willem Dafoe). Ocalił on Adama, czyniąc go swoim „zwierzakiem", zmuszając, aby mieszkał w kojcu z jego psem Reksem i zachowywał się jak on - siadał na żądanie, błagał, aportował czy udawał nieżywego. W 1958 roku Adam przyjeżdża do Izraela w poszukiwaniu starszej córki Rut. Tam dowiaduje się, że zmarła ona w czasie porodu. Ostatecznie bohater przeżywa załamanie i trafia do fikcyjnego, finansowanego ze środków amerykańskich, położonego na pustyni Negew Instytutu Rehabilitacji i Terapii im. Seizlinga - azylu dla osób, które przeżyły Szoa. Zakład staje się w powieści swoistą synekdochą Izraela.

W problemach Adama z tożsamością - postaci fikcyjnej, w której dopatrywać się wszakże można osób realnych - dostrzec można liczne podobieństwa do

72 Tamże, s. 66.

73 Zmartwychwstanie Adama. Reż. P. Schrader. Scen. N. Stollman. Niemcy-USA-Izrael 2008, 0:00:58-0:01:22.

${ }^{74}$ Urodzony w Tel Awiwie Joram Kaniuk (1930-2013) - pisarz, dziennikarz, malarz. Opublikował 17 powieści, 7 tomów opowiadań, 2 kolekcje esejów, 5 książek dla dzieci i młodzieży oraz wspomnienia. Powieść, o której mowa, nosząca w hebrajskim oryginale tytuł Adam Ben Kelew, a więc właściwie Człowiek, syn psa („Adam” po hebrajsku to także rzeczownik pospolity oznaczający po prostu „człowieka”), a w angielskim tłumaczeniu Seymoura Simckesa - Adam Resurrected (Zmartwychwstanie Adama), uważana jest za jedno z najważniejszych dzieł na temat Holokaustu. Nie była nigdy w całości tłumaczona na język polski, podobnie zresztą jak inne utwory Kaniuka. Tylko częściowo usprawiedliwia tę sytuację trudny, pełen groteski, surrealistyczny język autora Ostatniego Żyda. W Polsce ukazał się jedynie fragment Adama Ben Kelewa J. Kaniuka w tłumaczeniu Leszka Kwiatkowskiego pt. Adam, syn psa („Literatura na Świecie” 2004, nr 11-12, s. 287-311). 
perypetii Nelly Sachs, pochodzącej, tak jak bohater powieści Kaniuka, z Berlina. Kiedy Adam idzie cmentarną aleją na jerozolimski grób córki, czytamy:

Groby wynurzały się z ciemności, przebłyskując spomiędzy drzew i kamieni. Adam zastanawiał się nad poczuciem bezpieczeństwa, które go ogarnęło. Niewyraźne wspomnienie z obozu. Również tam, w otoczeniu czarnych baraków i koszar, czuł się w jakiś sposób bezpiecznie, ponieważ rozumiał - wiedział, gdzie się znajduje, na czym stoi. Tamte baraki wznieśli architekci, którzy razem z nim studiowali na uniwersytecie. Wywodzili się z tej samej kultury. Kultura, która stworzyła Adama Steina, stworzyła też ten obó $z^{75}$.

Z powodzeniem, na zasadzie pewnej kondensacji i przy całej świadomości ryzykowności owego zabiegu (w którym zestawiam perypetie postaci z kart powieści z realną), moglibyśmy również powiedzieć, że kultura niemiecka, która stworzyła Nelly Sachs, stworzyła też obozy.

Reasumując, poetka sięga do imaginarium kultury niemieckiej, dla niej przecież macierzystej, za którą tęskni, która kojarzy się jej z miłością, by pokazać, że po Holokauście podszyta jest ona nieuchronnie śmiercią. Odtąd w zachodzącej nad Germanią „krwi zachodzącego słońca” już zawsze rosnąć będzie wspomnienie Zagłady.

\section{Zamiast zakończenia Kilka słów o recepcji twórczości Nelly Sachs w kręgu niemieckojęzycznym}

Mamy więc w przypadku analizowanego wiersza do czynienia z paradoksalnym połączeniem tęsknoty za niemieckością - czasami dzieciństwa („kołysanki”) i przyrodą („fiołek”, „dąb”), wraz z nieodwracalną, przez tę samą niemieckość spowodowaną, stratą. Kiedy Nelly Sachs pisała ten utwór (przypomnę, pierwszy raz opublikowany w 1947 roku), przebywała na emigracji w Szwecji. Szczęśliwie, niejako w ostatniej chwili, na tydzień przed wydaniem wyroku kierującego ją do obozu koncentracyjnego, w maju 1940 roku udało jej się, dzięki pomocy Selmy Lagerlöf, polecieć tam wraz z leciwą już matką Margarete (1871-1950). Zamieszkały w Sztokholmie, a od 1952 roku poetka stała się obywatelką Szwecji ${ }^{76}$. Niemcy, odpowiedzialne za Zagładę, były dla niej także źródłem nieustannej tęsknoty. Przywiązanie Sachs do kraju lat dziecinnych okazało się

\footnotetext{
75 Tamże, s. 306.

76 Na temat życia poetki zob. R. Dinesen: Nelly Sachs. Eine Biographie. Frankfurt 1992.
} 
zatem swoistym syndromem - nomen omen - sztokholmskim. Poetka nie mogła się uwolnić od tego, co zadawało jej ból. Splot niemieckości, sumienia, nostalgii i cierpienia był nierozwiązywalny.

Kwestia skomplikowanej tożsamości Sachs okazała się szczególnie nośna dla światowej krytyki. Przykładowo, Dan Diner (niemiecki historyk) zwracał uwagę na „negatywną symbiozę” dwóch kultur - niemieckiej i żydowskiej - w twórczości poetki, tzn. taką, w której przepaść oddziela byłe ofiary od sprawców, czyniąc osiągnięcie pozycji pomiędzy nimi prawie niemożliwym ${ }^{77}$. Z kolei Katja Garloff (uczona amerykańsko-niemiecka), która krytykuje zresztą termin „negatywna symbioza”, mający - jej zdaniem - „tendencję do zacierania różnicy między ofiarami i sprawcami oraz zasłaniający różnorakie powiązania niemiecko-żydowskich pisarzy przesiedleńców po wojnie", pisze o jakby podwójnej diasporze poetki - tradycyjnej, żydowskiej, oraz poniemieckiej ${ }^{78}$.

Wiemy już mniej więcej, na czym polegał i jak trudny był stosunek autorki Widzów do Niemiec. Na zakończenie warto zadać również pytanie - a jaki był stosunek Niemiec do Sachs? Rozważając je, zastrzec jednak muszę, że z pewnością nie będzie to odpowiedź kompletna ani wyczerpująca. Przede wszystkim dlatego, że przytoczona jedynie pobieżnie, wyliczona raczej niż omówiona. Dokładne jednak prześledzenie recepcji niemieckojęzycznej wymagałoby odrębnego, dość obszernego szkicu. Ponadto przekraczałoby kompetencje językowe piszącego. W tym miejscu zauważę tylko, że pogłębiona analiza musiałaby uwzględniać rozmaite podziały wynikające z powojennej historii Niemiec. Przede wszystkim $\mathrm{z}$ pewnością istniały różnice $\mathrm{w}$ recepcji zachodnio- i wschodnioniemieckiej ${ }^{79}$. Oddzielną kwestią byłoby prześledzenie obecności poezji Sachs $\mathrm{w}$ dyskursie austriackim czy szwajcarskim ${ }^{80}$. Z powodu ograniczeń objętościowych zwrócę zatem uwagę jedynie na wybrane, węzłowe moim zdaniem elementy.

Cytowana już Katja Garloff zauważyła, że

wielu autorów, którzy po 1945 roku żyli poza Niemcami, ale kontynuowali pisanie po niemiecku, doświadczyło pozytywnego odbioru w zachodnich Niemczech po 1960 roku w wyniku traumatycznego powrotu tematu ludobójstwa i masowych wysiedleń. Jest to szczególnie widoczne w odniesieniu do co najmniej trzech pisarzy, którzy zyskali dużą popularność i którym przypisano różne role: Petera Weissa, który stał się pisarzem-wizytówką wygnania dla

77 Zob. D. Diner: Negative Symbiose: Deutsche und Juden nach Auschwitz. „Babylon” 1986, 1, s. 9-20.

${ }^{78}$ K. Garloff: Words from Abroad. Trauma and Displacement in Postwar German Jewish Writers. Detroit 2005, s. 6.

${ }^{79}$ Nawiasem mówiąc, tomy poetyckie In den Wohnungen des Todes i Sternverdunkelung ukazały się w Berlinie Wschodnim już w 1949 r. dzięki staraniom Johannesa R. Bechera. Za uwagę tę dziękuję anonimowemu/anonimowej Recenzentowi/Recenzentce tego szkicu.

${ }^{80} \mathrm{~W}$ dużej mierze zawdzięczam te uściślenia anonimowemu/anonimowej Recenzentowi/ Recenzentce, za którego/ej uwagi jestem niezmiernie wdzięczny. 
wiodącej niemieckiej grupy literackiej - Grupy 47; Nelly Sachs, która stała się symbolem pojednania między Niemcami i Żydami; Paula Celana, który zaczął być uznawany za jednego z najważniejszych poetów niemieckojęzycznych $\mathrm{XX}$ wieku ${ }^{81}$.

To bardzo mi bliska konstatacja. Rzeczywiście, wiele wskazuje na to, że po latach niemal całkowitej nieobecności na przełomie lat 50. i 60. Niemcy odkryli poezję autorki Widzów i uczynili z niej symbol żydowsko-niemieckiego pojednania po Zagładzie ${ }^{82}$. Związane to było z różnymi zachodzącymi wtedy wydarzeniami dyskursywnymi, które tworzyły przychylny dla jej twórczości klimat. Właśnie w tym czasie ukazywały się w Niemczech ważne teksty. Tylko w roku 1959 wydano na przykład fundamentalne dla rozliczenia z przeszłością powieści: Heinricha Bölla Bilard o wpół do dziesiątej (Billiard um halb zehn), Güntera Grassa Blaszany bębenek (Die Blechtrommel) i Uwe Johnsona Domniemania w sprawie Jakuba (Mutmaßungen über Jakob) ${ }^{83}$. Wznowiono też dziennik Anne Frank $(1960)^{84}$. Niebawem miały się odbyć głośno komentowane procesy Adolfa Eichmanna w Jerozolimie (1961) oraz drugi proces członków załogi Auschwitz we Frankfurcie nad Menem (1963-1965). W 1963 roku ze względu na podeszły wiek ustąpił z funkcji kanclerza NRF Konrad Adenauer (1876-1967). Ten zwolennik udzielenia amnestii byłym nazistom sprawował swoją funkcję niezmiennie od 1949 roku i zdaniem wielu krytyków uniemożliwiał rozliczenie zbrodni Trzeciej Rzeszy ${ }^{85}$.

Wszystkie te wydarzenia zbiegły się $\mathrm{w}$ czasie $\mathrm{z}$ pierwszą wizytą poetki w Niemczech w 1960 roku. Przyjechała tam po trzydziestu latach, pierwszy raz od swojej ucieczki wiosną 1940 roku. Jakże wymowne jest, że wizytę tę przypłaciła ostrym załamaniem nerwowym. Po powrocie do Szwecji została osadzona w klinice psychiatrycznej w Sztokholmie z diagnozą paranoicznej psychozy i zgodnie z ówczesnymi standardami medycznymi poddana elektrowstrząsom. Szpital opuściła dopiero po czterech miesiącach, choć leczyła się z przerwami właściwie do końca życia.

81 K. Garloff: Words..., s. 1.

${ }^{82} \mathrm{Na}$ ten temat zob. też E. BAHr: Nelly Sachs. Autorenbücher. München 1980, tu rozdz. I Rezeptionsgeschichte: Statt einer Einleitung, s. 9-28.

${ }^{83}$ Niedługo przetłumaczono je także na inne języki. W Polsce szybko, w 1961 r., nakładem wydawnictwa PAX, w tłumaczeniu Teresy Jętkiewicz, ukazał się jedynie Bilard o wpół do dziesiątej Heinricha Bölla, pozostałe wydano ze sporym opóźnieniem. Blaszany bębenek opublikowano po raz pierwszy w 1979 r. nakładem Niezależnej Oficyny Wydawniczej, dopiero w 1983 r. oficjalnie ukazał się w PIW-ie, w przekładzie Sławomira Błauta. Ostatnia z powieści - Domniemania $w$ sprawie Jakuba, urodzonego w 1934 r. w Kamieniu Pomorskim Uwe Johnsona, ukazała się w Polsce dopiero w 2008 r. (!), w tłumaczeniu Sławy Lisieckiej, nakładem wydawnictwa Czytelnik.

84 Pierwsze niemieckie wydanie ukazało się w 1950 r. nakładem Das Tagebuch.

85 Zob. np. N. FreI: Vergangenheitspolitik. Die Anfänge der Bundesrepublik und die NS-Vergangenheit. München 2012. 
W tym samym czasie twórczość Sachs osiąga w Niemczech apogeum popularności. Poetka otrzymuje kolejne nagrody - w 1961 roku od miasta Dortmund, a w 1965 roku Nagrodę Pokojową Księgarzy Niemieckich we Frankfurcie nad Menem. Zostaje też korespondencyjnym członkiem Otwartej Akademii Sztuki Miasta Hamburg oraz Bawarskiej Akademii Sztuk Pięknych. Jej popularność wzmacnia otrzymana (razem ze Szmuelem Josefem Agnonem) w 1966 roku Nagroda Nobla za „wybitne utwory liryczne i dramatyczne, analizujące los narodu żydowskiego" ${ }^{86}$. Po jakimś czasie pojawiają się jednak również głosy krytyczne, podkreślające, że autorkę honorowano głównie w ramach niemieckich wyrzutów sumienia. Była wręcz „maskotką pamięci”" a jej poezja zyskała status wyznacznika żałoby. Do tego stopnia, że można potraktować włączanie twórczości Sachs do niemieckiego dyskursu jako „substytut żałoby, która w innym przypadku by się w niemieckim języku nie dokonała" ${ }^{88}$. Z czasem odbiór poezji tej autorki w Niemczech, tak mocno uwikłany w tamtejszą politykę pamięci, podążał drogą od pełnego uznania (jako głęboko poruszająca aspekty katastrofalnej przeszłości), stopniowo ku częściowemu zanegowaniu (jako nazbyt sentymentalna, manierystyczna i wyraźnie nienowoczesna próba reprezentowania nieprzedstawialnego ${ }^{89}$.

Dziś utwory Sachs, w tym właśnie Widzów, czyta się głównie w niemieckich szkołach. Weszły one na stałe do niemieckiego, edukacyjnego kanonu. Sylwetkę poetki zaś honorują takie instytucje, jak Deutsche Post, wydając znaczki z jej podobizną ${ }^{90}$, czy władze Berlina, które w 1995 roku uczyniły ją patronką ulicy w berlińskim Hellersdorfie ${ }^{91}$. Znamienne, że to, co pierwotnie miało budzić sumienia (przypomnę, „Sumienie to żydowski wynalazek”) i stanowiło świadectwo powikłanych związków Sachs z kulturą niemiecką, zostało przez tę ostatnią zawłaszczone, zagadane, sprowadzone do szkolnej interpretacji, a przez to tak mocno spetryfikowane. Język symboliczny, mglisty, otwierający się - co stara-

${ }^{86} \mathrm{Na}$ stronie http://www.nobelprize.org/nobel_prizes/literature/laureates/1966/sachs-speech. html [data dostępu: 24.08.2017] można się również zapoznać z wykładem noblowskim poetki.

${ }^{87}$ Zob. K.M. Bower: Claiming the Victim: Tokenism, Mourning, and the Future of German Holocaust Poetry. In: German Studies in the Post-Holocaust Age: The Politics of Memory, Identity, and Ethnicity. Eds. A. Del Caro, J. Ward. Boulder 2000, s. 136.

${ }_{88}$ Tamże, s. 135.

${ }^{89} \mathrm{Z}$ nowszych prac na jej temat warto zwłaszcza wymienić: Christine Rospert: Poetik einer Sprache der Toten. Studien zum Schreiben von Nelly Sachs. Bielefeld 2004 oraz nowy, tematyczny numer „Text+Kritik“ poświęcony poetce (2017, Bd. 23). Redaktor nowego wydania „Text+Kritik“ Daniel Pedersen jest również autorem dysertacji na temat wczesnej twórczości Sachs, pt. Die Poetik der Tränen. Nelly Sachs Frühwerk bis zu „In den Wohnungen des Todes” (2016).

${ }^{90} \mathrm{~W} 1991 \mathrm{r}$. z okazji stulecia urodzin poetki wydano znaczek o nominale 100 fenigów, a w 2016 r. na 125. urodziny o nominale 70 centów.

${ }^{91}$ Ulica Nelly Sachs przebiega w pobliżu parku miejskiego Regine Hildebrandt i jest równoległa do ulicy Janusza Korczaka. Większość nazw w tym obszarze została wybrana spośród nazwisk postaci, które w taki czy inny sposób ucierpiały z powodu nazistowskiego terroru. 
łem się tu pokazać - na różnorakie interpretacje i asocjacje, podległ ogołoceniu. Kołysanka, dzięki której dyskurs przykrywa Zagładę, została zatem - wbrew słowom trzeciej strofy Widzów - wyśpiewana. Raz jeszcze trzeba więc wrócić do poezji, by ponownie poczuć niepokój.

\section{Bibliografia}

BAHr E.: Nelly Sachs. Autorenbücher. München 1980.

Berendsohn W.A.: Nelly Sachs: Einführung in das Werk der Dichterin jüdischen Schicksals. Darmstadt 1974.

Bezzel-Dischner G.: Poetik des modernen Gedichts. Zur Lyrik von Nelly Sachs. Bad Homburg 1970.

BŁoński J.: Biedni Polacy patrza na getto. „Tygodnik Powszechny” 1987, nr 2, s. 1 i 4.

Böll H.: Bilard o wpół do dziesiątej. Przeł. T. Jętkiewicz. Warszawa 1961.

Bower K.M.: Claiming the Victim: Tokenism, Mourning, and the Future of German Holocaust Poetry. In: German Studies in the Post-Holocaust Age: The Politics of Memory, Identity, and Ethnicity. Eds. A. Del Caro, J. Ward. Boulder 2000, s. 131-139.

Bower K.M.: Ethics and Remembrance in the Poetry of Nelly Sachs and Rose Ausländer. Rochester 2000.

Chwalewik W.: Z literatury angielskiej. Studia i wrażenia. Warszawa 1969.

Cirlot J.-E.: Słownik symboli. Przeł. I. Kania. Kraków 2000.

Czajkowski M., ks.: Grzech antysemityzmu. „Więź” 1998, nr specjalny: Pod wspólnym niebem. Tematy polsko-żydowskie, s. 138-148.

Dalej jest noc. Losy Żydów w wybranych powiatach okupowanej Polski. Red. B. ENGELKING, J. Grabowski. T. 1-2. Warszawa 2018.

Diner D.: Negative Symbiose: Deutsche und Juden nach Auschwitz. „Babylon” 1986, 1, S. 9-20.

Dinesen R.: Nelly Sachs. Eine Biographie. Frankfurt 1992.

Dischner G.: Die Lyrik von Nelly Sachs und ihr Bezug zur Bibel, zur Kabbala und zum Chassidismus. „Text+Kritik. Zeitschrift für Literatur“ 1969, Bd. 23: Nelly Sachs, s. $25-40$.

Dunton-Downer L., Riding A.: Szekspir. Przeł. D. Koper, R. Morusiewicz. Warszawa 2005.

Enzensberger H.M.: Droga Li... Rozmawiał J.S. Buras. „Literatura na Świecie” 1994, nr 6, s. 162-167.

Esser F., Hartung U.: Nazis, Pollution, and no Sex. Political Scandals as a Reflection of Political Culture in Germany. "American Behavioral Scientist" 2004, no 47 (8), s. $1040-1071$.

Fionetos A.: Flucht und Verwandlung. Nelly Sachs, Schriftstellerin, Berlin/Stockholm. Berlin 2010.

Forecki P.: Od Shoah do strachu. Spory o polsko-żydowską przeszłość i pamięć w debatach publicznych. Poznań 2010. 
Frei N.: Vergangenheitspolitik. Die Anfänge der Bundesrepublik und die NS-Vergangenheit. München 2012.

Fritsch-ViviÉ G.: Nelly Sachs. Monographie. 3. Aufl. Reinbek 2001.

Fromm E.: Zapomniany język. Wstęp do rozumienia snów, baśni i mitów. Przeł. J. MARZĘCKI. Wstęp K.T. Toeplitz. Warszawa 1972.

GARLOFF K.: Words from Abroad. Trauma and Displacement in Postwar German Jewish Writers. Detroit 2005.

GŁowiński M.: Esej Błońskiego po latach. „Zagłada Żydów. Studia i Materiały” 2006, nr 2, s. 12-20.

Goethe J.W.: Fiołek. Przeł. S. ZaręBsia. W: J.W. Goethe: Wybór poezji. Oprac. Z. CieCHANOWSKA. Wrocław 1955, s. 80-82.

Grass G.: Blaszany bębenek. Przeł. S. B£aut. Warszawa 1983.

Grothe W.: Astralmotive im Universum der Nelly Sachs. „Text+Kritik. Zeitschrift für Literatur" 1969, Bd. 23: Nelly Sachs, s. 13-24.

Gustaw Zieliński. Życie i dzieło. Red. M. Krajewski. Rypin 1988.

Johnson U.: Domniemania w sprawie Jakuba. Przeł. S. Lisiecka. Warszawa 2008.

Kaniuk J.: Adam, syn psa. Przeł. L. Kwiatkowski. „Literatura na Świecie” 2004, nr 11-12, s. 287-311.

KopalińsKi W.: Słownik symboli. Warszawa 2001.

Koprowska K.: Postronni? Zagłada w relacjach chłopskich świadków. Kraków 2018.

Krawiecka J.: Niezwykłe życie niemieckiej noblistki Nelly Sachs (1891-1970). „Historic@” 2008, nr 3, s. 30-42.

Krupa B.: Opowiedzieć Zagładę. Polska proza i historiografia wobec Holokaustu (1987-2003). Kraków 2013.

Krupa B.: Powrót. Studium przypadku. „Studia Litteraria et Historica” 2018, nr 7. Dostępne w Internecie: https:/ispan.waw.pl/journals/index.php/slh/article/view/ slh.1731 [data dostępu: 20.10.2019].

Ksiegga Hioba. Przeł. I. Cylkow. Kraków-Budapeszt 2008.

Lagercrantz O.: Versus über die Lyrik der Nelly Sachs. Berlin 1967.

Lichański S.: Poetka sumienia. „Literatura na Świecie” 1976, nr 7, s. 339-343.

Markiel T., SKibińska A.: „Jakie to ma znaczenie, czy zrobili to z chciwości?”. Zagłada domu Trynczerów. Warszawa 2011.

Norwid C.: Jak gdy kto ciśnie w oczy człowiekowi. W: C. Norwid: Pisma wszystkie. Zebrał, tekst ustalił, wstępem i uwagami krytycznymi opatrzył J.W. Gomulicki. T. 2: Wiersze. Cz. 2. Warszawa 1971, s. 82-83.

Norwid C.: Vade-mecum. Oprac. J. FerT. Wrocław-Warszawa-Kraków-Gdańsk-Łódź 1990.

Ostrowski M.: O liryce Nelly Sachs. „Filologia Germańska” [Piotrków Trybunalski] 2001, z. 2, s. 171-178.

Pedersen D.: Die Poetik der Tränen. Nelly Sachs Frühwerk bis zu „In den Wohnungen des Todes". Maszynopis. [B.m.] 2016.

Piszczatowski P.: Znacze//nie wiersza. Apofazy Paula Celana. Warszawa 2014.

Platon: Państwo. Przeł. W. Witwicki. Warszawa 1958.

Rauschning H.: Rozmowy z Hitlerem. Przeł. J. Hensel, R. Turczyn. Warszawa 1994.

Rose R.S.: Krytyczny słownik mitów i symboli nazizmu. Przeł. Z. Jakubowska, A. RuRARz. Warszawa 2006. 
Rosenfeld A.H.: Podwójna śmierć. Rozważania o literaturze Holocaustu. Przeł. B. Krawcowicz. Warszawa 2003.

Rospert Ch.: Poetik einer Sprache der Toten. Studien zum Schreiben von Nelly Sachs. Bielefeld 2004.

Roszak J.: Punkty, południki - poezja Nelly Sachs. „Topos” 2005, nr 3, s. 95-105.

SACHa M.: Dąb Goethego czyli o ochronie pomników przyrody w III Rzeszy. W: Poszukiwanie sensów. Lekcja z czytania kultury. Red. P. Kowalski, Z. Libera. Kraków 2006, s. 197-222.

Sachs N.: Koniec. Przeł. R. Krynicki. W: N. Sachs: Rozżarzone zagadki. Wiersze wybrane. Wybór i przeł. R. KRYNICKI. Kraków 2006, s. 99.

SACHS N.: Legenden und Erzählungen [„Legendy i opowiadania”. Berlin 1921.

Sachs N.: Męka, czasomierz obcej gwiazdy. Przeł. R. KRYnicki. W: N. Sachs: Rozżarzone zagadki. Wiersze wybrane. Wybór i przeł. R. KRYNICKI. Kraków 2006, s. 19.

Sachs N.: O the Chimneys. Selected Poems, Including the Verse Play, ELI. New York 1967.

SACHS N.: Werke. Kommentierte Ausgabe in vier Bänden. Bd. 1: Gedichte 1940-1950. Hrsg. M. Weichelt. Berlin 2010.

Sachs N.: Widzowie. Przeł. Z. Herbert. „Poezja” 1967, nr 2, s. 49 (przedruk: „Zeszyty Literackie" 2001, nr 74, s. 40).

Sachs N.: Wy, widzowie. Przeł. R. Krynicki. W: N. SAChs: Rozżarzone zagadki. Wiersze wybrane. Wybór i przeł. R. KRYNicki. Kraków 2006, s. 13.

Shakespeare W.: Feniks i Turkawka. Przeł. M. SŁomczyński. W: W. Shakespeare: Wiersze i poematy. Przeł. M. SŁomCzyŃski. Kraków 1977, s. 191-195.

SŁomczyński M.: Od tłumacza. W: W. Shakespeare: Wiersze i poematy. Przeł. M. SŁomCZyŃski. Kraków 1977, s. 255-259.

Stenzel J.: Zeichensetzung. Stiluntersuchungen an deutscher Prosadichtung. Göttingen 1966.

Stogowska A.M.: Wpisany w epokę: Gustaw Zieliński (1809-1881). Płock 1996.

Strzetelski J.: Posłowie. W: W. Shakespeare: Wiersze i poematy. Przeł. M. SŁomCZYŃsKi. Kraków 1977, s. 261-264.

Szafarz J.: Nelly Sachs. Poetka żydowskiego losu. W: Niemieckojęzyczni laureaci literackiej Nagrody Nobla. Red. K. Ruchniewicz, M. Zybura. Wrocław 2006, s. 159-171.

Szenspir W.: Hamlet. Przeł. J. Paszkowski. W: W. Szekspir: Dzieła dramatyczne. Oprac. S. Helsztý́ski, R. JaвŁkowska. T. 6: Tragedie. Warszawa 1958, s. 5-161.

„Szkoła ukraińska” w romantyzmie polskim. Szkice polsko-ukrainskie. Red. M. NesteRUK, S. Makowski, U. MakowsKa. Warszawa 2013.

„Text+Kritik. Zeitschrift für Literatur“ 2017, Bd. 23: Nelly Sachs.

Vedder U.: „Verhoffen“: Gedankenstriche in der Lyrik von Ingeborg Bachmann, Nelly Sachs und Paul Celan. In: Die Poesie der Zeichensetzung. Studien zur Stilistik der Interpunktion. Hrsg. A. Nebrig, C. Spoerhase. Berno 2012, s. 345-361.

Zarawska A.: Wyrazić niewyrażalne. Holocaust w poezji Nelly Sachs. „Studia Niemcoznawcze" 2007, T. 34, s. 339-351.

ZaręBIAnka Z.: Nelly Sachs: Cierpieć w czasie zabitym przez wieczność. „Topos” 2006, nr 5, s. 131-135.

Zieliński G.: Dwa sonety (na śmierć brata). W: Poezye Gustawa Zielińskiego. Wydanie zupełne poprzedzone życiorysem na podstawie listów poety skreślonym i ocena jego działalności przez dr. Piotra Chmielowskiego. Toruń 1901, s. 251. 
Zieliński G.: Miłość. W: Poezye Gustawa Zielińskiego. Wydanie zupetne poprzedzone życiorysem na podstawie listów poety skreślonym i ocena jego działalności przez dr. Piotra Chmielowskiego. Toruń 1901, s. 262.

Zieliński G.: Pożegnanie. W: Poezye Gustawa Zielińskiego. Wydanie zupełne poprzedzone życiorysem na podstawie listów poety skreślonym i ocena jego działalności przez dr. Piotra Chmielowskiego. Toruń 1901, s. 231.

Zieliński G.: Tulipan i fiołek. W: Poezye Gustawa Zielińskiego. Wydanie zupełne poprzedzone życiorysem na podstawie listów poety skreślonym i ocena jego działalności przez dr. Piotra Chmielowskiego. Toruń 1901, s. 235-236.

Żukowski T.: Wytwarzanie „winy obojętności” oraz kategorii „obojętnego świadka” na przykładzie artykułu Jana Błońskiego „Biedni Polacy patrza na getto”. „Studia Litteraria et Historica” 2013, nr 2. Dostępne w Internecie: https://ispan.waw.pl/journals/ index.php/slh/article/view/slh.2013.018 [data dostępu: 20.10.2019].

Bartłomiej Krupa

A Violet, an Old Oak, and the Shoah

Nelly Sachs's "Ihr Zuschauenden" and Symbolic Language

\section{Summary}

This text is devoted to Nelly Sachs's "Ihr Zuschauenden," published in a volume entitled In den Wohnungen des Todes (1947). Beginning with a comparative reading of English and Polish translations (including those by Zbigniew Herbert and Ryszard Krynicki), this article distances itself from the frequently used category of a witness, understood as a passive observer of the Holocaust, and proposes to focus on the complex figure of the spectator of the Shoah. Furthermore, the symbolic language (Fromm) of Sachs's poem is analysed as well, as the article describes its connections with Judaism and German culture. The figures of a turtle, a well, and - more importantly - a violet and an oak seem to allude not only to romanticism, but also to Shakespearean tropes. Significantly, an oak might also symbolise the German genesis. Such links paradoxically merge the sense of childhood nostalgia ("a lullaby") and German natural landscape ("a violet," "an oak") with irretrievable loss caused by the Shoah. The last part of the article is dedicated to the reception of Sachs's works, which, unnoticed at first, turned out to be the paragon of the Holocaust literature in the 1960, and then were appropriated and reduced to a school canon by the German culture she problematised so well in her works.

Key words: German poetry, Nelly Sachs, Holocaust, bystanders, poetic language 